\title{
Jazykové vzdělávání pro dospělé přistěhovalce v České republice a ve Švédsku a používání cílového jazyka účastníků těchto kurzů
}

\author{
Milena Öbrink Hobzová
}

\begin{abstract}
Abstrakt: Cílem předkládané studie je na pozadíaktuálnínabídky jazykového vzdělávání pro dospělé přistěhovalcev obou zemích prezentovat výsledky výzkumu, jenž byl proveden v jazykových kurzech pro dospělé přistěhovalce jak v České republice, tak Švédsku v roce 2012. Zmíněné šetřenísi kladlo za cíl zjistit, zda existují rozdíly v situacích, v nichž účastníci vzdělávání v České republice a ve Švédsku používají cílový jazyk. Teoretická východiska pro zmíněný výzkum se opírala o autory, kteří se věnují jazykovému vzdělávání cizinců: Carlson (2006), Lindberg \& Sandwall (2007), Chvojková (2009), Hádková (2010). Výzkumu se zúčastnilo 95 respondentů z České republiky a 222 respondentů ze Švédska. Jako metodu sběru dat jsme použili nestandardizovaný dotazník. Po ověření hypotéz testem nezávislosti chí-kvadrát pro kontingenční tabulku jsme mohli konstatovat, že mezi situacemi, v nichž hovoři účastníci jazykového vzdělávání cílovým jazykem v České republice a Švédsku, je statisticky významný rozdíl.
\end{abstract}

Klíčová slova: kurzy češtiny pro přistěhovalce, kurzy švédštiny pro přistěhovalce (SFI), vzdělávání imigrantů, tradice jazykového vzdělávání pristěhovalců, integrace pristěhovalců

\section{1 ÚVOD}

Žijeme v době, kdy si musíme nejen v celé Evropské unii, ale také v České republice zvyknout na fakt, že se budeme potkávat s lidmi-migranty, kteřise rozhodli odejít ze své země a začít nový život v zemi jiné. Začlenění (integrace) přistěhovalců do přijímací společnosti je dlouhodobý a oboustranný proces, ke kterému je zásadním klíčem znalost jazyka majoritní společnosti. Bez něho nebude mít nově př́chozí možnost najít si zaměstnání, nepochopí kulturu ani hodnoty majority. Nenajde si v nové zemi přátele a v budoucnu se nebude moci s danou společností identifikovat.

Pro sociální pedagogy je integrace přistěhovalců (a to nejen dětí přistěhovalců, ale také těch z řad dospělých) aktuálním tématem. Mohou se při své práci stát nápomocni tomu, aby se zmínění jedinci neocitli na okraji společnosti. Sociální pedagog se může setkat s dětmi cizinců v hodinách českého jazyka jako asistent pedagoga či jako vychovatel nebo pedagog volného času v zařízeních volného času. S dospělými cizinci navazuje kontakt v občanských sdruženích (např. SOZE, Občanské sdružení Berkat aj.) či v Centrech na podporu integrace cizinců (více o nich níže), která se věnují poradenství (nejen v oblasti kurzů češtiny pro cizince) zmíněné skupině dospělých. Zároveň sociální pedagog najde své uplatněnív uprchlických táborech Ministerstva vnitra. Důležitou roli však sociální pedagog zastává při preventivníčinnosti, nebot může vychovávat a vést jak přislušníky majority, tak minority ke snášenlivosti a toleranci. Tím se jeho práce promítá do multikulturní výchovy.

K provedenínašeho výzkumného šetření nás především vedla aktuálnost tématu migrace i integrace nově př́chozích do majoritní společnosti - a to jak v České republice, tak ve Švédsku. Protože Švédsko často sloužíjako model integrace přistěhovalců (viz výsledky výzkumu MIPEX (2014), v němž se po zhodnocení integračních opatření uvedená severská země pravidelně umístuje na prvním místě), zajímalo nás srovnání používání cílového jazyka u dospělých přistěhovalců v této severské 
zemi a České republice. Cílem výzkumného šetření bylo zjistit, zda existují rozdíly v situacích, v nichž účastníci vzdělávání(z řad dospělých přistěhovalců) v České republice a ve Švédsku používají češtinu a švédštinu, a zda existuje rozdíl mezi muži a ženami v průměrech používání cílového jazyka v různých situacích.

\section{TEORETICKÁ VÝCHODISKA VÝZKUMU}

\subsection{Vývoj jazykového vzdělávání pro dospělé přistěhovalce na pozadí migrace ve Švédsku}

Migrace po 2. sv. válce proměnila relativně kulturně a jazykově homogenní Švédsko v multikulturní společnost, jakou je nyní ve druhém desetiletí 21. století. Podle SCB (2014) pobývalo ve Švédsku $v$ roce 2013 celkem 694662 cizinců ( $v$ roce 2012 žilo na území Švédska 667232 cizinců). Počet cizích státních příslušníků se v porovnání se 60 . lety 20. století téměř zšestinásobil (v roce 1960 zde bylo 190621 cizinců).

I když ve Švédsku mohou přistěhovalci využít jazykových kurzů jak na Högskola a ve studijních kroužcích, tzv. studieförbund ${ }^{1}$, většina z nich dochází do kurzů Svenskundervisning för invandrare (dále SFI), kterými se budeme $v$ našem příspěvku dále zabývat a jež představují základní jazykové vzdělávání pro přistěhovalce. Podle statistiky Skolverket ${ }^{2}$ navštěvovalo kurzy SFI v roce 2011 cca 102400 studentů (Skolverket, 2012, 1).

Kořeny kurzů SFI Ize hledat v roce 1965. Tehdy byla znalost jazyka považována za podmínku $k$ tomu, aby se noví přistěhovalci úspěšně usadili na území Švédského království. Výuka švédštiny pro imigranty byla organizována $v$ malých studijních kroužcích, které nabízely soukromé organizace většinou jako večerní kurzy jedenkrát či dvakrát týdně. Neexistovalo žádné formální kurikulum pro uvedené kurzy a rovněž nebyly stanoveny požadavky na vzdělání učitelů, kteří výuku vedli (Tingbjörn, 2004, 743).

Důležitým zl omem se stal rok 1986, kdy se kurzy SFI staly programem v systému vzdělávání. Stagnace SFI začala však ve 2. polovině 90 . let, nebot' se tehdy negativně projevila decentralizace školského systému ve Švédsku: stát měl omezenou možnost regulovat vzdělávací cíle, zatímco sylabus mohli dotvářet prímo učitelé nebo jej vytvářely samy školy podle svých podmínek. Avšak kvůli výběrovým ř́zením, která byla pravidelně vypisována na realizaci SFI, se pro mnoho učitelů stalo jejich zaměstnání velmi nestabilní, tím klesala jejich profesní motivace více se $v$ kurzech angažovat. To se negativně promítlo do kvality kurzů. Zmíněná stagnace byla částečně zastavena zavedením národní jazykové zkoušky v roce 1996 (Lindberg, Sandwall, 2007, 85).

Vznik kurzů SFI však podpořil nejen zájem o další vzdělávání přistěhovalců, ale také výzkum v oblasti švédštiny coby druhého jazyka a didaktiky v tomto oboru (např. Granberg, 2001; Carlson, 2006).

Zmíněné jazykové SFI jsou poskytovány osobám, které mají pobyt na území Švédska a jež ve druhé polovině kalendářního roku dosáhnou 16 let. Tito lidé nemusejí mít žádné znalosti švédštiny (Skolverket, 2013a). Toto vzdělávání si podle výše zmíněného švédského úřadu Skolverket (Skolverket, 2013b) klade za cíl vybavit dospělé, kteří mají jiný mateřský jazyk než švédštinu, základními znalostmi švédštiny. Zároveň by jim mělo poskytnout takové jazykové kompetence, které by jim zajistily komunikaci a aktivní účast v každodenním společenském a pracovním životě. Úkolem SFI je také umožnit dospělým, kteří mají minimální či žádné dovednosti v oblasti čtení a psaní, získat gramotnost (Skolverket, 2013b). V praxi jde v tomto prípadě často o azylanty.

${ }^{1}$ Obě dvě možnosti Ize zařadit spiše do neformálního vzdělávání.

${ }^{2}$ Skolverket (v angličtině Swedish National Agency for Education) byl Ježkovou a kol. $(2011,33)$ do češtiny přeložen jako Švédská národní agentura pro vzdělávání. Jde o státní úřad, který kontroluje a vyhodnocuje vzdělávání na školách a v dalších organizacích. 
Kurzy SFI nabízejíobce, které majíze zákona povinnost vypsat výběrové řízení na jejich poskytování. SFI je určeno jak azylantům, tak pracovním přistěhovalcům ze zemí EU či tzv. třetích zemí.

Systém SFI se dělído tři vzdělávacích stupňů, tzv. „Studieväg“ 1 (skládá se z kurzů A, B), „Studieväg“ 2 (zahrnuje kurz B a C) a "Studieväg“ 3 (zahrnuje kurzy C, D). Všechny tři uvedené kurzy se zaměřují na různé skupiny přistěhovalců, kteří mají za sebou různé vzdělání a mají rovněž jiné cíle. Zatímco stupeň 1 se soustředí na dospělé s nízkým vzděláním, do kurzů stupně 3 docházejí lidé s vyšším stupněm vzdělání, u kterých se předpokládá, že majíjiž vytvořené učební strategie $k$ tomu, aby se naučili nový jazyk. Proto se u každého vzdělávacího stupně liší počet hodin, kdy je výuka přistěhovalce dotována v rámci SFI (Skolverket, 2012, 9).

Kurzy odpovídají jazykovým kompetencím podle Společného evropského jazykového referenčního rámce. Kurz $A$ je na úrovni $A 1-/ A 1$, kurz $B$ odkazuje na úroveň $A 1 / A 2$, kurz $C$ na $A 2 / A 2+$ a $D$ na $B 1 / B 1+$ (Skolverket, 2012, 9). Po kurzech B, C a D následuje národní zkouška (Skolverket, 2012, 9-10), jejiž složení či nesložení nemá vliv na udělení nebo neudělení trvalého pobytu a švédského občanství.

Ačkoliv jsou uvedené kurzy vnímané jako jedno z integračních opatření švédské vlády, stávají se terčem kritiky. To vede $k$ neustálé reformě kurzů, což se negativně podepisuje na jejich kvalitě. $\checkmark$ praxi bývá uvedené vzdělávání spojováno také s možnostmi dalšího vzdělávání dospělých, které jim umožňuje získat profilaci v nějakém oboru (např. kuchař, vychovatel ve školce apod.).

\subsection{Vývoj jazykového vzdělávání pro dospělé přistěhovalce na pozadí migrace v České republice}

V porovnáníse Švédskem má Česká republika kratší zkušenost s migrací, i když to neznamená, že by před rokem 1989 žádná mezinárodní migrace na území tehdejší Československé socialistické republiky (dále ČSSR) neprobíhala. Naopak - Drbohlav (2010, 25-27) podotýká, že se mezinárodní migrace projevovala snahou občanů ČSSR nelegálně emigrovat do zemí západního světa a zároveň sem na základě mezinárodních dohod směřovali pracovníci z Polska, Vietnamu, Kuby, Angoly či Mongolska a dalších států (Drbohlav, 2010, 25-27).

Pro studenty, kteří přijeli do bývalého Československa před rokem 1989, byly zajištěny přípravné kurzy českého jazyka. Zvláště intenzivně probíhala výuka především vietnamských občanů, kteří přicestovali do Československa na základě bilaterálních dohod o spolupráci. Jak zmiňuje Kocourek (2008), nejvyššínárůst Vietnamců v bývalém Československu Ize zaznamenat mezi lety 1979 až 1985, kdy prijižžděly dva druhy skupin: žáci, kteří měli studovat na středních odborných školách s možnou následnou praxí, a dále praktikanti a stážisté. Po př́jezdu do Československa museli učni absolvovat intenzivníkurz českého jazyka, jenž trval tři měsíce. V př́padě, že jazykovou zkoušku po kurzu zvládli, začali studovat na středních odborných učilištích. Po třech letech studia směli jít do výrobní praxe. Tříměsiční kurzy byly povinné rovněž pro praktikanty či dělníky před tím, než nastoupili na příslušná pracoviště (Kocourek, 2008).

Po listopadu 1989 nastal kvůli nové společensko-politické situaci živější kontakt se zahraničím, a proto vzrostl zájem ze strany cizinců o český jazyk. Navazování osobních i pracovních kontaktů s nimi přineslo v tomto ohledu podle Hádkové $(2010,31)$ nové úkoly pro češtinu. To se odrazilo v nabídce jazykového vzdělávání. Zahraničnístudenti si mohli zlepšovat své znalosti v kurzech, které pořádala střediska Ústavu jazykové a odborné přípravy Univerzity Karlovy v Praze, nebo na letních školách slovanských studií, jež probíhaly na univerzitách v Praze, Brně a Olomouci a které měly své kořeny před rokem 1989. K těmto zahraničním studentům se však přidávali i další, již chtěli získat základníkomunikačnídovednosti v češtině. Zároveň se na univerzity dostali studenti, kteří pobývali v rámci programu Erasmus na území České republiky pouze jeden nebo dva semestry a také se potřebovali naučit základnífráze v češtině. Z tohoto důvodu vznikaly intenzivní kurzy, které si kladly za cíl orientovat se právě na výše zmíněné posluchače různých univerzitních oborů (Hádková, 2010, 32). Poptávku po českém jazyce ve skupinách přistěhovalců začaly také uspokojovat jazykové školy či 
jazykové agentury, které nabízely kurzy českého jazyka pro cizince v rámci mimoškolního, neformálního vzdělávání dospělých.

Také dokumenty integračnípolitiky České republiky se zmiňují o nutnosti poskytovat jazykové kurzy pro cílovou skupinu cizinců. Integrační politika se v současnosti snaží zajistit „nejširší regionální dostupnost kurzů českého jazyka pro dospělé cizince, a to pro různé stupně pokročilosti, včetně kurzů profesního jazyka“ (Vláda ČR, 2013, 9).

Podle Českého statistického úřadu (2014) žilo na území České republiky k 31. prosinci 2013 celkem 441536 cizinců, kteři pocházeli z více než 180 zemí světa. Nejvíce cizinců do České republiky proudí z Ukrajiny, na druhém místě je Slovensko, poté Vietnam a Rusko (Český statistický úr̆ad, 2014).

Jako motivačnífaktor $k$ tomu, aby se cizinci na území České republiky co nejdř́ive naučili česky, měla sloužit zkouška z českého jazyka, kterou je nutné doložit $k$ žádosti o trvalý pobyt v př́padě cizinců z tzv. třetích zemí (Chvojková, 2009) a také k žádosti o udělení občanství (zákon o státním občanství České republiky - č. 186/2013 Sb.). Požadavek doložení této zkoušky zvětšuje poptávku po kurzech češtiny jako cizího jazyka mezi dospělými.

V porovnáníse Švédskem, kde je všem přistěhovalcům (jak těm z Evropské unie - dále EU, azylantům, tak imigrantům ze třetích zemí) nabídnut stejný jazykový program (jazykové kurzy SFI), se v České republice možnosti různí. Imigranti z EU či zemí mimo EU nebo azylanti mohou využít kurzy, které jsou poskytovány jazykovými školami a jazykovými agenturami. Zmíněné jazykové kurzy jsou však zpoplatněny, což může pro některé skupiny přistěhovalců znamenat jistou finanční zátěž, kvůli které tuto službu nebudou využívat.

Ti jedinci, jimž byla na území České republiky udělena nějaká forma mezinárodní ochrany, mohou rovněž využít tzv. Státní integračníprogram. Kurz by neměl přesáhnout 10 měsíců a absolvent by po jeho ukončení měl obdržet osvědčení o absolvování (Uherek a kol., 2012, 109). Kurzy také nabízejí občanská sdružení, která se zaměřují na pomoc výše uvedeným skupinám (přikladem může být Sdružení občanů zabývající se emigranty - SOZE, jehož posláním je poskytovat pomoc uprchlíkům a dalším cizincům, kteří přicházejí do České republiky).

Bezplatné jazykové kurzy poskytují i Centra na podporu integrace cizinců (dále CPIC), která nabízejí kromě bezplatných jazykových kurzů také poradenskou činnost, sociokulturní kurzy, prístup na internet a do knihovny. Služby jsou určeny cizincům, kteří pocházejí z nečlenských zemí EU a kteří mají na území České republiky platný trvalý či dlouhodobý pobyt.

CPIC patří pod Správu uprchlických zařízení, což je rozpočtová organizace Ministerstva vnitra (dálejen SUZ MV ČR). Uvedená centra vznikla s cílem podpořit integraci cizinců, která by byla dlouhodobá a koncepční. Činnost prvních čtyř center byla zahájena v červenci roku 2009. Služby, které zmiňovaná centra poskytují, jsou bezplatné. Aktivity uvedených center jsou spolufinancovány z Evropského integračního fondu. Centra fungují zatím v Ostravě (Moravskoslezský kraj), Pardubicích (Pardubický kraj), Plzni (Plzeňský kraj), Liberci (Liberecký kraj), Českých Budějovicích (Jihočeský kraj), ve Zlíně (Zlínský kraj), v Olomouci (Olomoucký kraj) a Karlových Varech (Karlovarský kraj). V roce 2013 vzniklo nové centrum v Jihlavě na Vysočině (SUZ MV ČR, Centra na podporu integrace cizinců, 2013). Působnost integračních center se $v$ současné době rozšíril la také mimo hlavní regionální centra (např. jazykové kurzy v Olomouckém kraji neprobíhajíjen v Olomouci, ale jsou poskytovány také v Přerově a Šumperku).

Centra na podporu integrace cizinců jsou organizace, ve kterých by se v budoucnu mohli uplatnit absolventi oboru sociální pedagogika. Poskytují totiž cizincům poradenskou a informační činnost (ta byla v souladu se zákonem č. 108/2006 Sb. vykazována jako základní sociální poradenství), dále jsou centra poskytovateli registrovaného sociálního poradenství (a to podle zákona č. 108/2006 Sb., zákona o sociálních službách, se jedná o „odborné sociální poradenstvi“ a "terénní programy“). Ve zmíněných centrech jsou také dostupné sociokulturní kurzy, jež jsou zaměřeny na cizince 
s dlouhodobým pobytem. Zároveň zde mohou cizinci navštěvovat př́pravné kurzy $\mathrm{k}$ testu z českých reálií pro udělení českého státního občanství (SUZ MV ČR, Centra na podporu integrace cizinců, 2013). Na rozdíl od švédského SFI, které se soustře dí pouze na švédštinu společně s předáním základních znalostí o švédské kultuře a společnosti, se snaží CPIC fungovat jako prostředník mezi minoritou (cizinci) a majoritou. $V$ nabídce Ize proto najít programy, které se zaměřujín na multikulturní výchovu (akce pro děti, workshopy ve spolupráci s místními organizacemi - knihovnami, středisky volného času).

\section{HLAVNÍ ČÁST EMPIRICKÉ STUDIE}

\subsection{Cíle výzkumu}

Cílem našeho výzkumu bylo zjistit, zda existují rozdíly v situacích, v nichž účastníci vzdělávání z řad přistěhovalců v České republice a ve Švédsku používají cílový jazyk. Na základě studia pramenů a odborné literatury předpokládáme, že se delší zkušenost Švédska pozitivněji odrazí v každodenní komunikaci přistěhovalců s většinovou společností. Očekáváme, že se budou přistěhovalci ve Švédsku snažit ve větším počtu použivat cílový jazyk se svými práteli a v každodenních situacích.

Zároveň bylo naším úkolem zjistit, zda existuje rozdíl mezi muži a ženami v průměrech používání cílového jazyka v různých situacích.

\subsection{Výzkumné otázky a hypotézy}

Výzkumné otázky zněly:

- Existují v České republice a Švédsku rozdíly v situacích, v nichž hovoří účastníci jazykového vzdělávání cílovým jazykem?

- Existují v obou zemích rozdíly mezi muži a ženami v průměrech používání cílového jazyka?

V návaznosti na výzkumné otázky a cíle výzkumu jsme zformulovali následující věcné hypotézy:

Věcná hypotéza č. 1: Situace, ve kterých hovoři účastníci jazykového vzdělávání cílovým jazykem, se liší.

\section{Statistická hypotéza č. 1:}

$\mathrm{H}_{0}$ : Mezi situacemi, v nichž hovoři účastnícijazykového vzdělávánícilovým jazykem v České republice a Švédsku, neexistuje statisticky významný rozdil.

$\mathrm{H}_{\mathrm{A}}$ : Mezi situacemi, v nichž hovoři účastníci jazykového vzdělávání cilovým jazykem v České republice a Švédsku, je statisticky významný rozdil.

Věcná hypotéza č. 2: $V$ průměrech používánícílového jazyka u mužů a u žen existuje významný rozdil.

\section{Statistická hypotéza č. 2:}

$\mathrm{H}_{0}: V$ průměrech používání cilového jazyka u mužů a u žen neexistuje významný rozdíl.

$\mathrm{H}_{\mathrm{A}}: V$ průměrech používání cílového jazyka u mužů a u žen existuje významný rozdíl.

\subsection{Výzkumné metody}

Pro náš výzkum jsme zvolili kvantitativní strategii, která umožňuje ověřovat a vysvětlit dané jevy a získat pro ně objektivní důkazy. Získaná data jsme poté tř́ílili na úrovni prvního i druhého stupně (Ryšavý, 2002). K ověřování první hypotézy jsme použili test nezávislostichí-kvadrát pro kontingenční 
tabulku (vzorec uveden na obrázku 1). Pro interpretaci rozdílů v testu nezávislosti chí-kvadrát pro kontingenčnítabulku jsme zvolili z-skóre (viz obrázek 2). Pro ověřování druhé hypotézy jsme využili program IBM SPSS Statistics 21.

$$
\chi^{2}=\frac{(p-o)^{2}}{o}
$$

Obrázek 1. Vzorec pro výpočet testu nezávislosti chí-kvadrát pro kontingenční tabulku (Chráska, 2007)

$$
z=\frac{n \times n_{p}-n_{r} \times n_{s}}{\sqrt{n_{r} \times n_{s} \times(n-n) \cdot\left(n-n_{s}\right)}} \times \sqrt{n}
$$

Obrázek 2. Výpočet z-skóre (Chráska, 2007)

Ke sběru dat jsme použili nestandardizovaný dotazník ${ }^{3}$, jenž se jevil jako nejpraktičtější vzhledem k velikosti reprezentativního souboru a nutnosti získat data ze dvou od sebe velmi vzdálených zemí. Protože pro nás bylo dopředu nemožné zjistit, z jakých zemí respondenti pocházejí, vytvořili jsme dotazník ve švédsko-anglické mutaci. V České republice byly po konzultaci s pracovníky CPIC v Olomouckém kraji vyhotoveny dotazníky v české mutaci, česko-anglické jazykové mutaci, dále $\checkmark$ ruské, ukrajinské a vietnamské verzi. Abychom zajistili to, že překladem do cílového jazyka nedojde k nesprávné interpretaci českého originálu, postupovali jsme následovně: nejdříve byla česká verze přeložena do výše uvedených jazyků. Poté byly překlady převedeny do češtiny a bylo výzkumníkem zkontrolováno, zda vše odpovídá původnímu znění položek.

Respondenti odpovídali na otázku „Kdy mluvíte česky/švédsky?“ a mohli vybrat více odpovědí z následujících možností: Jen v kurzu. / Doma s rodinou. / S práteli. / V práci. / S úřady. / Jinde, napište prosím, kde.

Výzkum jsme realizovali v obou zemích během roku 2012. Převážnou část dat jsme získali během května a června tohoto roku. Vzhledem $\mathrm{k}$ tomu, že v té době nebyly kurzy v moravských Centrech na podporu integrace cizinců zcela naplněny, rozhodli jsme se ještě získat data - především v olomouckém Centru - na konci roku 2012. Nedostatečná návštěvnost kurzů v Centrech způsobila, že rozsah vzorku na české straně je poměrně malý.

V České republice proběhl výzkum na CPIC v Olomouci, Pardubicích, Ostravě a Zlíně. Ve Švédsku jsme dotazníky distribuovali v kurzech SFI na soukromé jazykové škole Hermods v Uppsale a Stockholmu a v komunitním centru SFI Söderort ve Stockholmu. Všechna místa byla v rámci výzkumu vylosována náhodným výběrem.

\subsection{Výzkumný vzorek}

Ve Švédsku se našeho výzkumu zúčastnilo celkem 227 respondentů. Mohli jsme však vyhodnotit pouze odpovědi od 222 z nich, nebot u zbylých 5 nebyla data úplná. $V$ České republice jsme oslovili celkem 102 respondentů, z nichž jsme obdrželiúplné informace od 95 respondentů. Jsme si vědomi toho, že mezi rozsahem výzkumného souboru ve Švédsku a České republice panuje jistý nepoměr, avšak počet respondentů byl ovlivněn ochotou a také možnostmi škol s námi spolupracovat. Ve Švédsku se výzkumu zúčastnilo 155 žen a 67 mužů, průměrný věk respondentů byl 34,30 let. V České

${ }^{3}$ Dotazník byl použit autorkou ke zpracování dat sloužících k vypracování dizertační práce s názvem Tradice a perspektivy jazykového vzdělávání dospělých cizinců ve Švédsku a České republice, která byla obhájena v dubnu 2014 na Ústavu pedagogických a sociálních studií Pedagogické fakulty Univerzity Palackého v Olomouci. Obsahoval cel kem 28 položek, které si kladly za cíl zjistit názory a motivy k jazykovému vzdělávání dospělých přistěhovalců v obou zemích. 
republice jsme získali data od 95 respondentů. Žen v českém vzorku byla většina: celkem jich odpovědělo 56 , mužů bylo v našem výběru 39. Průměrný věk respondenta v České republice byl v porovnání se Švédskem nižší, tj. 31,81 let.

Respondentů ve Švédsku bylo nejvíce z Iráku (24), Íránu (14) a ze Somálska (16). Celkem studující pocházeli z více než 64 zemí. Toto zastoupení respondentů odpovídá tomu, ze kterých zemí přistěhovalci v SFI pocházejí.

V České republice pocházeli respondenti z 34 různých zemí celého světa. Výzkumu se zúčastnilo 19 Vietnamců, 17 Rusů a 14 Ukrajinců. Z jiných třetích zemí bylo 45 respondentů. Toto zastoupení opět odpovídá migračním vinám, které jsou pro Českou republiku typické.

\subsection{Výsledky výzkumu a jejich interpretace}

Jak ukazuje níže nabízený obrázek 3 s tabulkou 1, nejčastější používání češtiny u respondentů v České republice jsme zaznamenali v prípadě komunikování s přáteli $(52, \mathrm{tj} .55 \%)$, v práci $(50, \mathrm{tj} .53 \%)$ a s úřady $(49$, tj. $52 \%)$. Pouze $v$ rámci kurzu komunikuje 39 respondentů, což je méně než v prípadě švédských účastníků. Ti nejvíce používají švédský jazyk jen v hodinách SFI (155, tj. 70 \%). Na druhém místě nejčastěji používali švédští respondenti cílový jazyk při kontaktech se svými práteli (101 odpovědí, což je téměř polovina všech respondentů, tj. $45 \%$ ).

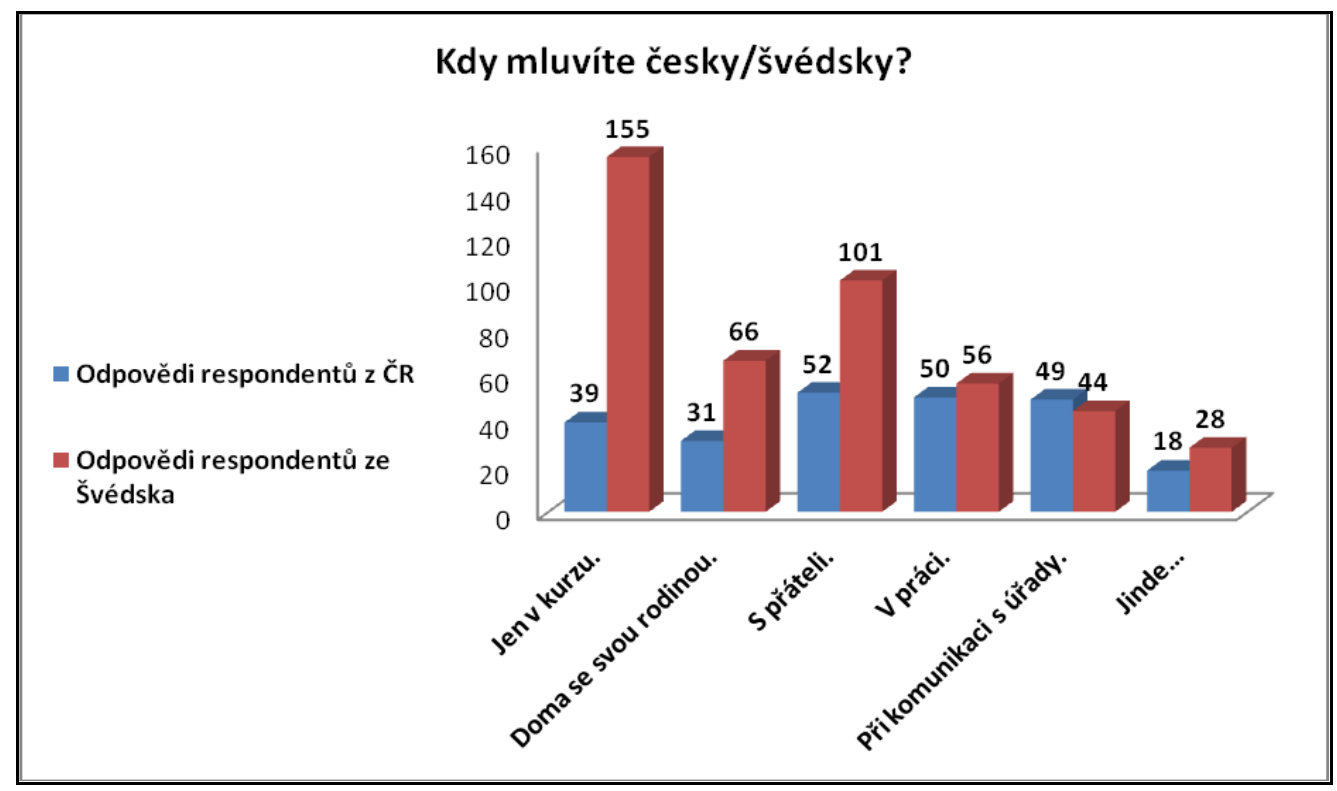

Obrázek 3. Kdy mluvíte česky/švédsky?

Tabulka 1

Kdy mluvíte česky/švédsky?

\begin{tabular}{lcccc}
\hline Odpovědi & \multicolumn{2}{c}{$\begin{array}{c}\text { Respondenti v České republice } \\
\text { Absolutníčetnost }\end{array}$} & $\begin{array}{c}\text { Respondenti ve Švédsku } \\
\text { Relativníčetnost }\end{array}$ & $\begin{array}{c}\text { Absolutníčetnost } \\
\text { Relativníčetnost }\end{array}$ \\
\hline Jen v kurzu. & 39 & $41 \%$ & 155 & $70 \%$ \\
Doma s rodinou. & 31 & $33 \%$ & 66 & $30 \%$ \\
S přáteli. & 52 & $55 \%$ & 101 & $45 \%$ \\
V práci. & 50 & $53 \%$ & 56 & $25 \%$ \\
S úřady. & 49 & $52 \%$ & 44 & $20 \%$
\end{tabular}


Volných odpovědísi respondenti v České republice spiše nevšímali. Pokud ano, zmiňovali se o tom, že česky mluvínejčastěji v restauraci, obchodech (10 respondentů), „,v̌̌ude, kde to jde“ (1 respondent). U švédských účastníků kurzu SFI jsme kromě situacív obchodě ( 6 respondentů) zaznamenali několik zajímavých vyjádření, jež budeme níže citovat:

Když se nedomluvím anglicky.

Normálně mimo SFI spiše mocse Švédy nemluvím, docela se stydím, protože švédština je těžká na výslovnost.

Myslím si, že je důležité, abychom chodili někam se Švédy. V kurzu jsou totiž lidé, kteří tu nemají žádné prátele, proto mluvi švédsky jen ve škole, a to je pak těžké se naučit švédsky, když nemáte $s$ kým mluvit.

Chtěla bych mluvit švédsky, ale nikde nemám přiležitost švédsky mluvit mimo kurz. Všude mluvím jen svým jazykem, to mi vadí.

Švédsky mluvím na úr̆adu práce a ve zdravotnípojištóvně.

Snažím se používat švédštinu i mimo školu, ale jde to těžko.

Po vyhodnocení uvedené volné odpovědi jsme si kladli otázku, zda je opravdu švédská společnost vůči cizincům tak uzavřená, že se přistěhovalci minimálně dostanou do kontaktu se švédskou majoritou. Pozitivní naopak je, že někteří z nich cvičí švédštinu, když dělají úkoly se svými dětmi. Domníváme se proto, že děti jsou pro dospělé velkou motivací, proč se nový jazyk dále učit.

Výše zformulované hypotézy jsme vyhodnocovali testem chí-kvadrát pro kontingenční tabulku. Získaná hodnota byla $\chi^{2}=39,298$, což znamená, že byla vyšší než kritická hodnota pro daný stupeň volnosti $\chi^{2} 0,05(4)=9,488$. Mohli jsme tedy odmítnout nulovou hypotézu a prijmout hypotézu alternativní. Konstatovali jsme, že: Mezi situacemi, v nichž hovoři účastníci jazykového vzdělávání cílovým jazykem v České republice a Švédsku, je statisticky významný rozdil.

Získané výsledky jsme se pokusili interpretovat pomocí z-skóre.

Tabulka 2

Kontingenčnítabulka s hodnotamipro ověřováníhypotézy č. 1 a hodnotamiz-skóre

\begin{tabular}{|c|c|c|c|c|c|c|}
\hline & & Jenv kurzu. & Doma s rodinou. & S prráteli. & V práci. & Při komunikaci s úřady. \\
\hline \multirow[t]{2}{*}{$P$} & ČR & 39 & 31 & 52 & 50 & 49 \\
\hline & SV & 155 & 66 & 101 & 56 & 44 \\
\hline \multirow[t]{2}{*}{0} & ČR & 66,678 & 33,339 & 52,586 & 36,432 & 31,964 \\
\hline & SV & 127,322 & 63,661 & 100,414 & 69,568 & 61,036 \\
\hline \multirow{2}{*}{$\frac{(P-O)^{2}}{o}$} & ČR & 11,489 & 0,164 & 0,007 & 5,053 & 9,079 \\
\hline & SV & 6,017 & 0,086 & 0,002 & 2,646 & 4,755 \\
\hline$\chi^{2}$ & 39,298 & & & & & \\
\hline $\begin{array}{l}f=(r-1) \\
\cdot(s-1)\end{array}$ & 4 & & & & & \\
\hline \multirow{2}{*}{$\begin{array}{l}\text { hodnoty } \\
\text { z - skóre }\end{array}$} & Česko & $-5,007$ & $-0,543$ & $-0,114$ & 3,036 & 4,022 \\
\hline & Švédsko & 5,007 & 0,543 & 0,114 & $-3,036$ & $-4,022$ \\
\hline
\end{tabular}




\begin{tabular}{lllllll} 
z- skóre & Česko & --- & 0 & 0 & ++ & +++ \\
& Švédsko & +++ & 0 & 0 & -- & --- \\
\hline
\end{tabular}

Na základě interpretace znaménkem po použití z-skóre Ize tedy konstatovat následující:

1. Respondenti ve Švédsku používají cílový jazyk, tj. švédštinu, nejvíce v kurzu. V práci a při komunikaci s úřady švédští účastníci mluví švédsky méně.

2. Respondenti v České republice komunikují česky nejvíce s úřady a dále také v práci.

Výše uvedenévýsledky se také odrazily ve vzájemných korelacích mezi situacemi, které jsme zjištovali v programu IBM SPSS Statistics 21. Získaná korelace potvrzuje vzájemnou souvislost mezi sledovanými jevy. Ti respondenti, kteří více hovořili cílovým jazykem jen v kurzu, používali jazyk majority méně často $v$ práci či při komunikaci $s$ úřady či doma $s$ rodinou. Ti, kteř́ komunikovali $v$ cílovém jazyce $s$ rodinou doma, mluvili tímto jazykem častěji také s práteli. Respondenti, kteří používali cílový jazyk v práci, jím častěji hovořili v kontaktu s úřady.

Tabulka 3

Korelace mezi jednotlivýmisituacemi

\begin{tabular}{|c|c|c|c|c|c|c|c|}
\hline & & $\begin{array}{c}\text { Česko } 1 \\
\text { Švédsko } 2\end{array}$ & $\begin{array}{c}\text { Jen } \\
\text { v kurzu. }\end{array}$ & $\begin{array}{c}\text { Doma } \\
\text { s rodinou. }\end{array}$ & S přáteli. & V práci. & $\begin{array}{l}\text { Při komunikaci } \\
\text { s úřady. }\end{array}$ \\
\hline $\begin{array}{l}\text { Česko1 } \\
\text { Švédsko2 }\end{array}$ & $\begin{array}{l}\text { Pearson } \\
\text { Correlation }\end{array}$ & 1 & ,280* &,- 024 &,- 081 &,$- 261^{* *}$ &,$- 309^{*}$ \\
\hline & $\mathrm{N}$ & 317 & 317 & 317 & 317 & 317 & 317 \\
\hline Jen v kurzu. & $\begin{array}{l}\text { Pearson } \\
\text { Correlation }\end{array}$ & $280^{* *}$ & 1 &,$- 261^{* *}$ &,$- 354^{* *}$ &,$- 222^{* *}$ &,$- 280^{*}$ \\
\hline & $\mathrm{N}$ & 317 & 317 & 317 & 317 & 317 & 317 \\
\hline $\begin{array}{l}\text { Doma } \\
\text { s rodinou. }\end{array}$ & $\begin{array}{l}\text { Pearson } \\
\text { Correlation }\end{array}$ &,- 024 &,$- 261^{* *}$ & 1 & ,169** &,$- 131^{*}$ &,- 080 \\
\hline & $N$ & 317 & 317 & 317 & 317 & 317 & 317 \\
\hline S přáteli. & $\begin{array}{l}\text { Pearson } \\
\text { Correlation }\end{array}$ &,- 081 &,$- 354^{* *}$ & $169^{* *}$ & 1 & ,027 & 122 \\
\hline & $N$ & 317 & 317 & 317 & 317 & 317 & 317 \\
\hline V práci. & $\begin{array}{l}\text { Pearson } \\
\text { Correlation }\end{array}$ &,$- 261^{* *}$ &,$- 222^{* *}$ &,$- 131^{*}$ & 027 & 1 & ,159* \\
\hline & $\mathrm{N}$ & 317 & 317 & 317 & 317 & 317 & 317 \\
\hline $\begin{array}{l}\text { Při } \\
\text { komunikaci }\end{array}$ & $\begin{array}{l}\text { Pearson } \\
\text { Correlation }\end{array}$ &,$- 309^{* *}$ &,$- 280^{* *}$ &,- 080 &, $122^{*}$ &, $159^{* *}$ & 1 \\
\hline s úrady. & $\mathrm{N}$ & 317 & 317 & 317 & 317 & 317 & 317 \\
\hline
\end{tabular}

Pearson Correlation - Pearsonův korelační koeficient; N - celkový počet respondentů jak ve Švédsku, tak $\checkmark$ České republice

Druhá věcná hypotéza zněla: $V$ průměrech použivání cílového jazyka u mužů a u žen existuje významný rozdil. 
Tabulka 4

Popisná statistika výsledků dotazníku pro ověrováníhypotézyč. 2

\begin{tabular}{|c|c|c|c|c|c|}
\hline Pohlaví & & $\mathrm{N}$ & Mean & $\begin{array}{l}\text { Std. } \\
\text { Deviation }\end{array}$ & $\begin{array}{l}\text { Std. Error } \\
\text { Mean }\end{array}$ \\
\hline \multirow[t]{2}{*}{ Jen v kurzu. } & 1,0 & 106 & 604 & 4914 & 0477, \\
\hline & 2,0 & 211 & ,626 & ,4851 & ,0334 \\
\hline \multirow[t]{2}{*}{ Doma s rodinou. } & 1,0 & 106 & 311 & 4652, & ,0452 \\
\hline & 2,0 & 211 & ,308 & ,4628 & ,0319 \\
\hline \multirow[t]{2}{*}{ S přáteli. } & 1,0 & 106 & ,453 & ,5001 & ,0486 \\
\hline & 2,0 & 211 & ,502 & ,5012 & ,0345 \\
\hline \multirow[t]{2}{*}{ V práci. } & 1,0 & 106 & ,406 & 4934 & 0479, \\
\hline & 2,0 & 211 & ,303 & ,4608 & ,0317 \\
\hline \multirow[t]{2}{*}{ Při komunikaci s úřady. } & 1,0 & 106 & ,311 & ,4652 & ,0452 \\
\hline & 2,0 & 211 & ,294 & ,4566 & ,0314 \\
\hline
\end{tabular}

N - celkový počet respondentů, Mean - průměr, Std. Deviation - směrodatná odchylka, 1,0 - muži, 2,0 -ženy

Deskriptivníanalýza přinesla zjištění, že průměry používání cílového jazyka v závislosti na pohlaví se významně neliší.

Pro zodpovězení výzkumného cíle jsme provedli statistické porovnání průměrů používání cílového jazyka u žen a u mužů v celém výzkumném souboru. Pro zjištění signifikantního rozdílu mezi rozptyly u těchto skupin byl použit Levenův test rovnosti rozptylů (viz tabulka 5). T-test, který porovnává rozdíl v průměru ve skupinách muži a ženy, ukázal, že hodnota $\mathrm{P}$ (Sig. 2-tailed) byla ve všech situacích většínež $\alpha(0,05)$, proto nelze odmítnout nulovou hypotézu: v průměrech použivání cílového jazyka u mužů a u žen neexistuje významný rozdíl.

Tabulka 5

Levenův test rovnostirozptylů pro ověřováníhypotézyč. 2

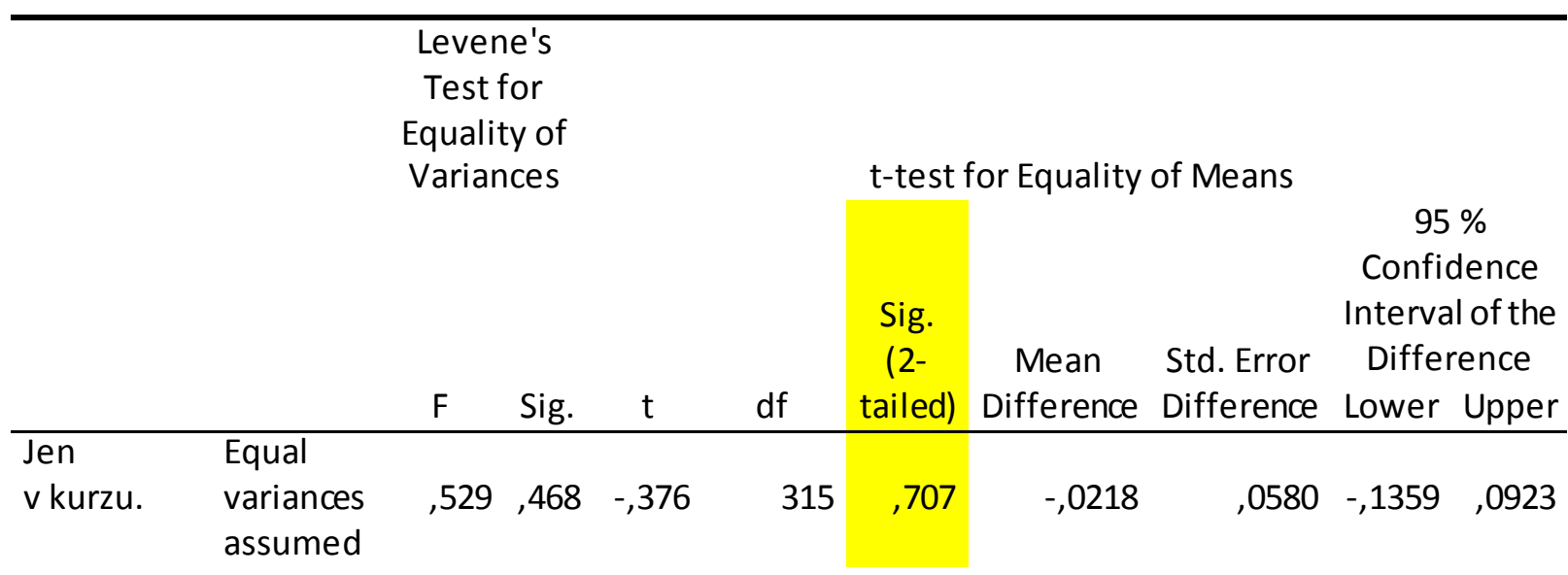




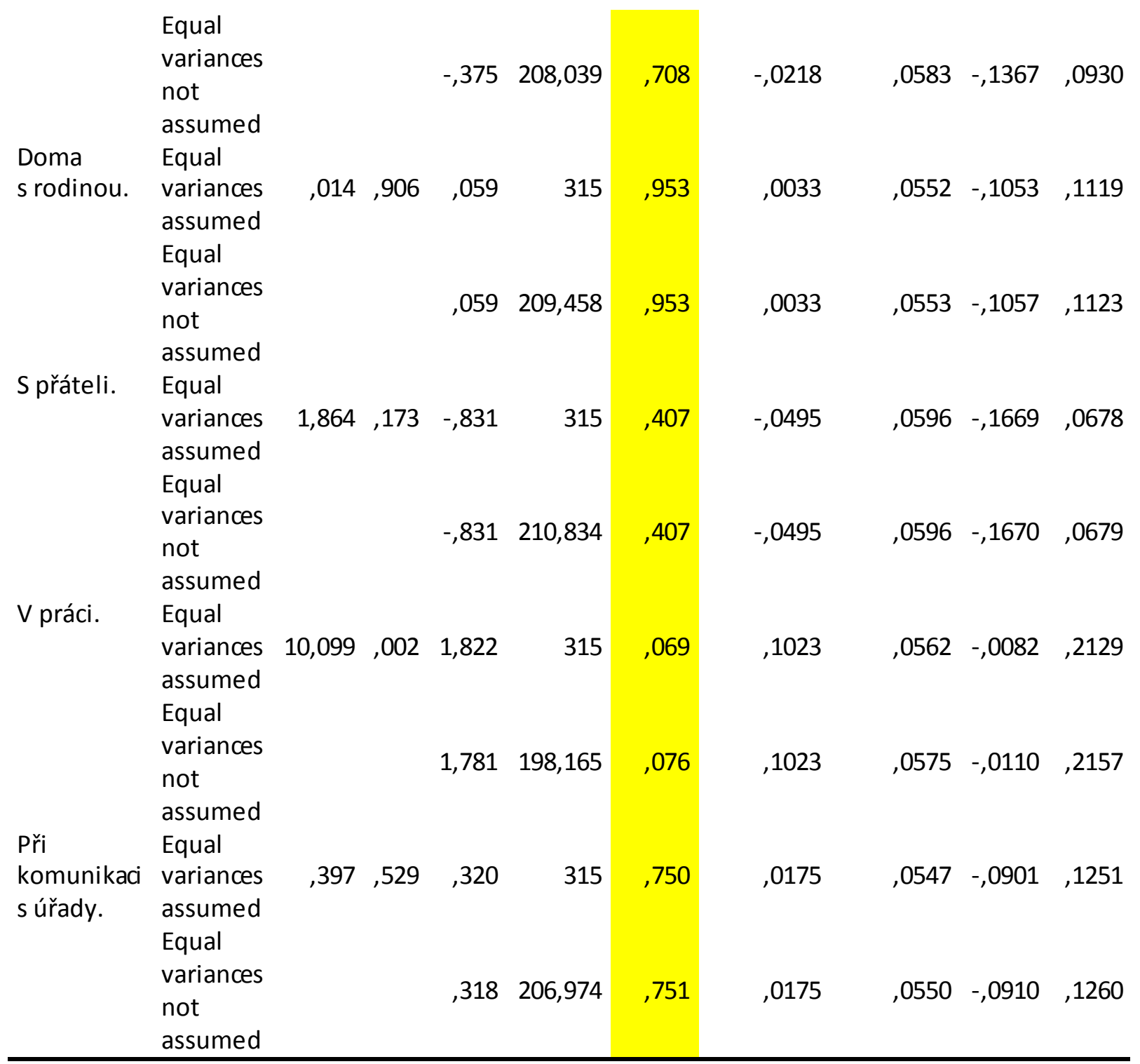

Na základě ověření první hypotézy jsme dospěli k tomu, že mezi situacemi, v nichž hovoří účastníci jazykového vzdělávání cílovým jazykem v České republice a Švédsku, je statisticky významný rozdíl. Interpretace získaných hodnot z-skóre poukazuje na to, že respondenti ve Švédsku používají cílový jazyk nejvíce $v$ kurzu, zatímco účastníci v České republice nejvíce česky hovoří s úřady a dále také $\checkmark$ práci. $V$ rámci druhé hypotézy jsme však nemohli odmítnout nulovou hypotézu: dospěli jsme tedy k závěru, že v průměru používání cílového jazyka u mužů a u žen neexistuje významný rozdíl.

Lze tvrdit, že se $v$ této části analýzy našich otázek projevilo to, co se již objevilo v závěrech výzkumu Elmeroth (2003). Uvedená autorka upozorňovala na to, že účastníci kurzů SFI se téměř nesetkávají s majoritou, proto švédštinu používají pouze v kurzu. Podobným způsobem používajíćl ový jazyk také respondenti, kteři se ve Švédsku zúčastnili našeho výzkumného šetření.

Z výše uvedených výsledků se Ize domnívat, že čeští přistěhovalci mají více přiležitostík tomu, aby používali v praxi své znalosti češtiny, což může vést ke stimulaci jejich vnitřní motivace a v konečném důsledku efektivnější integraci do české společnosti.

Je sice možné, že ve Švédsku existuje větší možnost, že přistěhovalci se mohou v každodenních situacích domluvit anglicky. Přesto je však švédština bezpodmínečně nutná pro jejich úspěšnou integraci - to platí pro každou skupinu přistěhovalcủ (at' těch, kteří miríi do dané země za prací, nebo těch, kteří hledají azyl). 
Náš výzkum mohl však odkrýt další problémy: snaha švédských integračních programů nabídnout účastníkům kurzu SFI praxi v nějakém podniku či zařizení tak, aby se začlenili do pracovního trhu, stejně v konečném důsledku selhává. Účastníci hovoří švédsky většinou pouze v kurzu, pokračují $v$ jeho studiu, aniž by jej trénovali v praxi při komunikaci s většinou. Nedostatek komunikace mezi cizinci a většinou může být ve Švédsku výsledek neúspěšné integrace, nebot' cizinci žijí v izolovaných částech měst, ve kterých bydlí minimum Švédů a které se potýkají se sociálními nepokoji (např. Rosengård v Malmö).

V České republice výsledky našeho výzkumu mohly poukázat na to, že většina z těch, kteři docháze jí do jazykových kurzů na CPIC, nejsou izolováni od většiny. Jsou alespoň nuceni používat český jazyk $v$ praxi (při kontaktu $s$ práteli). Je možné, že se $v$ tomto rozdílu odráží, že někteří přistěhovalci pocházející z Ukrajiny a Ruska lépe rozumějí česky kvưli svému mateřskému jazyku. Přesto je ale nutné zdůraznit, že češtinu používajís přáteli, takže se s Čechy stýkají. To může znamenat, že česká společnost není vůči cizincům tak uzavřená. Můžeme si jen prát, aby také $v$ budoucnu byla oboustranná komunikace v české společnosti podporována a zamezilo se segregaci cizinců.

Výzkum poukazuje na významnou roli sociálního pedagoga, který může přispět ke zlepšení komunikace mezi většinou a cizinci - a to at již v rámci sociálního poradenství, nebo při aktivitách s danou skupinou (či dětmi cizinců) ve volném čase. Tím bude docházet ke stimulaci použivání cílového jazyka prirrozenou cestou.

\section{ZÁVĚR}

Naším výzkumným cílem bylo zjistit, zda existují rozdíly v situacích, v nichž používají účastníci cílový jazyk v České republice a ve Švédsku. Na základě ověření hypotéz jsme dospěli k závěru, že mezi situacemi, v nichž hovoří účastníci jazykového vzdělávání cílovým jazykem v České republice a Švédsku, je statisticky významný rozdíl. Na základě interpretace získaných hodnot z-skóre jsme vyslovili výroky, že respondenti ve Švédsku používají cílový jazyk nejvíce v kurzu, zatímco účastníci v České republice nejvíce hovoří česky s úřady a dále také v práci.

Vzhledem k tomu, že respondenti v České republice hovoříčesky se svými přáteli, domníváme se, že Ize podporovat rozvoj jejich jazykových schopnostíi v rámci vol ného času. Proto by bylo možné se při různých kulturně společenských a sportovních akcích realizovaných v klubech, centrech, spolcích, v zájmových organizacích apod. více soustředit (např. ve spolupráci s Centry na podporu integrace cizinců) na dospělé přistěhovalce. Rozvíjet výše zmíněné aktivity by především měly školy, do nichž dochází především děti cizinců. Hlavně zmíněné školy by mohly uspořádat různé volnočasové sportovní, kulturní, či zábavné aktivity, programy, akce pro rodiny s dětmi, v rámci kterých by měli i dospělí přistěhovalci (rodiče dětí) častější př́ležitost komunikovat $v$ češtině nejen s ostatními imigranty, ale také s majoritou.

Rovněž si troufáme tvrdit, že je nezbytné podpořit veškeré vzdělávací akce, které by zvýšily u prìistěhovalců i majority sociokulturní povědomí o sobě navzájem. $Z$ tohoto důvodu by měly být opět podporovány kampaně a edukační programy, jež by zvyšovaly sociokulturní znalosti menšiny o majoritě a majority o menšinách - a to jak ve Švédsku, tak v České republice.

\section{LITERATURA}

Carlson, M. (2006). Images and values in textbooks and practice: Language courses for immigrants in Sweden. In Carlson, M., Rabo, A., \& a Gök F. (Eds.). Education in 'Multicultural' Societies Turkish and Swedish Perspectives (123-140). Stockholm. Dostupné z: <http://srii.org/content/upload/documents/acd26eOf-2c52-46c3-97a9-2df83707535f.pdf>. 
Český statistický úřad. (2014). Cizinci: Počet cizinců [online]. In Český statistický úřad-Statistiky. [cit. 14. 7. 2014]. Dostupné z: <http://www.czso.cz/csu/cizinci.nsf/tabulky/ciz_pocet_cizincu001\#.U-SxhKNHK1C>.

Elmeroth, E. (2003). From Refugee Camp to Solitary Confinement: Illiterate Adults Learn Swedish as a Second Language. Scandinavian Journal of Educational Research, 27 (4). 431-449.

Grandberg, N. (2001). The dynamics of second language learning. Umeå: Umeå University, Department of Contemporary Literature and Scandinavian Languages.

Hádková, M. (2010). Čeština z druhé strany, aneb, Čeština v roli jazyka nemateřského. Ústí nad Labem: [Univerzita J. E. Purkyně, Pedagogická fakulta].

Chráska, M. (2007). Metody pedagogického výzkumu: základykvantitativního výzkumu. Praha: Grada.

Chvojková, P. (2009). Pro či proti integraci? Problematika povinné zkoušky z češtiny pro udělení trvalého pobytu v kontextu integrace cizinců v ČR. In Kultura-média-komunikace (185-203). Sv. II. Olomouc: Univerzita Palackého, Centrum kulturálních, mediálních a komunikačních studií.

Ježková, V. et al. (2011). Školní vzdělávání ve Švédsku. Praha: Karolinum.

Kocourek, J. (2008). Stručný historický přehled o česko-vietnamských vztazích a působení Vietnamců $\checkmark$ ČR [online]. In ASI-milovaní. [cit. 14. 5. 2013]. Dostupné z: <http://www.asimilovani.estranky.cz/clanky/narodnosti-v-cr/vietnamci.html>.

Lindberg, I. \& Sandwall, K. (2007). Nobody's darling? Swedish for adult immigrants: A critical perspective. Prospect, 42(3), 79-95. Dostupné z:<http://www.ameprc.mq.edu.au/docs/prospect_journal/volume_22_no_3/Nobodys_darling. pdf $>$.

MIPEX (2014). Migrant Integration Policy Index [online]. [cit. 9. 7. 2014]. Dostupné z: $<$ http://www.mipex.eu/countries>.

SUZ MV ČR. (2012). Závěrečná monitorovací zpráva - Provoz center na podporu integrace cizinců VI [online]. In Integracnicentra.cz. [cit. 12. 8. 2013]. Dostupné na: <http://www.integracnicentra.cz/KeStazeni/KeStazeni.aspx>.

Ryšavý, D. (2002). Metody a techniky sociálního výzkumu. Olomouc: Univerzita Palackého $\checkmark$ Olomouci. Studijní texty pro distanční studium.

SCB. (2014). Helårsstatistik - Riket befolkning efter födelseland och ursprungsland [online]. In Statistiska centralbyrån. [cit. 10. 7. 2014]. Dostupné z: < http://www.statistikdatabasen.scb.se/pxweb/sv/ssd/START_BE_BE0101_BE0101F/UtImed bR/?rxid=7ccd541c-b9f9-4389-95bb-c63ee257d81f>.

Skolverket. (2012). Utbildning i svenska för invandrare - kursplan och kommentarer. Stockholm: Skolverket.

Skolverket. (2013a). Who is the education intended for? [online]. In Skolverket.se. [cit. 9. 4. 2013]. Dostupné na internetu:<http://www.skolverket.se/om-skolverket/andra-sprak-och-lattlast/inenglish/the-swedish-education-system/2.883/2.900/who-is-the-education-intended-for1.103807>.

Skolverket. (2013b). What is Swedish tuition for immigrants. [online]. In Skolverket. [cit. 17. 7. 2013]. Dostupné na internetu: < http://www.skolverket.se/om-skolverket/andra-sprak-ochlattlast/in-engl ish/the-swedish-education-system/2.883/2.900/what-is-swedish-tuition-forimmigrants-1.103806>. 
SUZ MV ČR, Centra na podporu integrace cizinců. (2013). Poskytované služby [online]. In $\begin{array}{lllllll}\text { Integracnicentra.cz. } & \text { [cit. } & 23 . & 8 . & 2014] & \text { Dostupné } & \end{array}$ $<$ http://www.integracnicentra.cz/Default.aspx>.

Tingbjörn, G. (2004). Svenska som andraspråk i ett utbildningspolitiskt perspektiv - en till bakablick. In Hyltenstam, K. \& Lindberg, I. (Ed.), Svenska som andraspråk-iforskning, undervisning och samhälle (717-761). Lund: Författarna och Studentlitteratur.

Uherek, Z. et al. (2012). Analýza státního integračního programu pro azylanty. Praha: Etnologický ústav AV ČR.

Vláda České republiky. (2013). Usnesenívlády České republiky ze dne 16. ledna 2013 č. 43 k Postupu při realizaci aktualizované Koncepce integrace cizinců - Společné soužití v roce 2013 [online]. In Mvčr.cz. [cit. 20. 7. 2013]. Dostupné z:<http://www.mvcr.cz/clanek/integrace.aspx>.

Zákon o státním občanství České republiky -č. 186/2013 Sb.

\title{
Autor
}

Mgr. Milena Öbrink Hobzová, Ph.D., Univerzita Palackého v Olomouci, Cyrilometodějská teologická fakulta, Katedra křestanské výchovy, Univerzitní 22, 71111 Olomouc, e-mail:milenahobza@email.cz

Text této studie vznikl díky projektu Za hranice multikulturalismu. Filozoficko-pedagogické aspekty multikulturního vzdělávání? podpořeného na Filozofické fakultě Univerzity Palackého v Olomouci v roce 2014 z Fondu pro podporu vědecké činnosti.

\section{The offer in language training for adult immigrants in the Czech Republic and Sweden and the course participants' use of the target language in practice}

\begin{abstract}
Using the background of current offers in language training for adult foreigners, the aim is to present the results of the research which was conducted in language courses for adult immigrants in both the Czech Republic and Sweden in 2012. This aim of the research was to determine whether there were differences in the situations in which learners in the Czech Republic and Sweden use the target language. The research theory was based on the authors who deal with language education for foreigners: Carlson (2006) Lindberg \& Sandwall (2007), Chvojková (2009), Hádková (2010). The sample included 95 respondents from the Czech Republic and 222 respondents from Sweden. As a method of data collection, a non-standardized questionnaire was used. To verify the stated hypothesis the chi-square test of independence and contingency tables were applied. As a result, we could state that there was a statistically significant difference in the situations in which respondents spoke the target language in the Czech Republic and Sweden.
\end{abstract}

Key words: Czech courses for immigrants, Swedish courses for immigrants(SFI), immigrant education, traditions of language education for immigrants, integration of immigrants 